\title{
DATING OF THE UPPER PLEISTOCENE LITHIC INDUSTRY OF SARDINIA
}

\author{
G KLEIN HOFMEIJER* C ALDERLIESTEN** \\ K VAN DER BORG**, C M HOUSTON**, A F M DE JONG** \\ FABIO MARTINI ${ }^{\dagger}$, MARIO SANGES $^{\dagger}, \mathrm{P}^{\text {Y Y SONDAAR* }}{ }^{*}$ \\ and \\ J A DE VISSER*
}

ABSTRACT. During an excavation of 1986 and 1987, a joint team from Utrecht, Siena and the Soprintendenza di Sassari e Nuoro, found a pre-Neolithic lithic industry in Corbeddu Cave, Oliena, Sardinia, which was dated to $8000-17,000 \mathrm{BP}$. The artifact typology is different from that of the mainland of the same period. The lithic and bone artifacts suggest an endemic isolated economy of the Upper Pleistocene in Sardinia.

\section{INTRODUCTION}

In 1982 excavations began in Corbeddu Cave, Oliena, Sardinia. In the second hall of this cave fossils of the endemic deer, Megaloceros cazioti, were within a pre-Neolithic deposit. Both the taphonomy of the bones (Sondaar et al, 1984, 1986), and associated human fossil remains (Spoor \& Sondaar, 1986), confirmed a pre-Neolithic occupation. Artificial modification and spatial distribution of the deer bones suggest a human use of the bones that is unknown on the mainland from this period. Together with the aberrant morphology of the human fossils, the finds suggest endemism resulting from isolation in a biotope with only three species of large mammals, ochotonid (Prolagus sardus), deer (Megaloceros cazioti) and a small canid (Cynotherium sardous). ${ }^{14} \mathrm{C}$ dates made at the Robert J Van de Graaff Laboratorium indicated a Late Pleistocene to Early Holocene association (Klein Hofmeijer et al, 1987b).

This paper deals with the lithic industry which was mainly found in Hall 1 (Fig 1). Finds from Hall 1 and Hall 2 are correlated with ${ }^{14} \mathrm{C}$ dates.

A Lower-Paleolithic lithic industry from northern Sardinia indicates human presence on the island dating to the Middle Pleistocene (Arca et al, 1982; Martini \& Pitzalis, 1981, 1982).

\section{STRATIGRAPHY OF HALL 1}

Figure 2 shows three stratigraphic units in Hall 1, the youngest of which contains Bronze-Age ceramics and bones of Prolagus sardus and domesticated animals.

Layer B contains, besides ceramics, flint, quartz, obsidian and bones of

\footnotetext{
* Instituut voor Aardwetenschappen, Rijksuniversiteit Utrecht, PO Box 80.021, 3408 TA Utrecht, TheNetherlands

** Robert J Van de Graaff laboratorium, Rijksuniversiteit Utrecht, PO Box 80.000, 3508 TA Utrecht, The Netherlands

Dipartimento di Archcologia e Storia delle arte sezione di Preistoria, Universitá Siena, Siena, Italy

Suprintendenza Archeologica di Sassari e Nuoro, Nuoro, Italy
} 


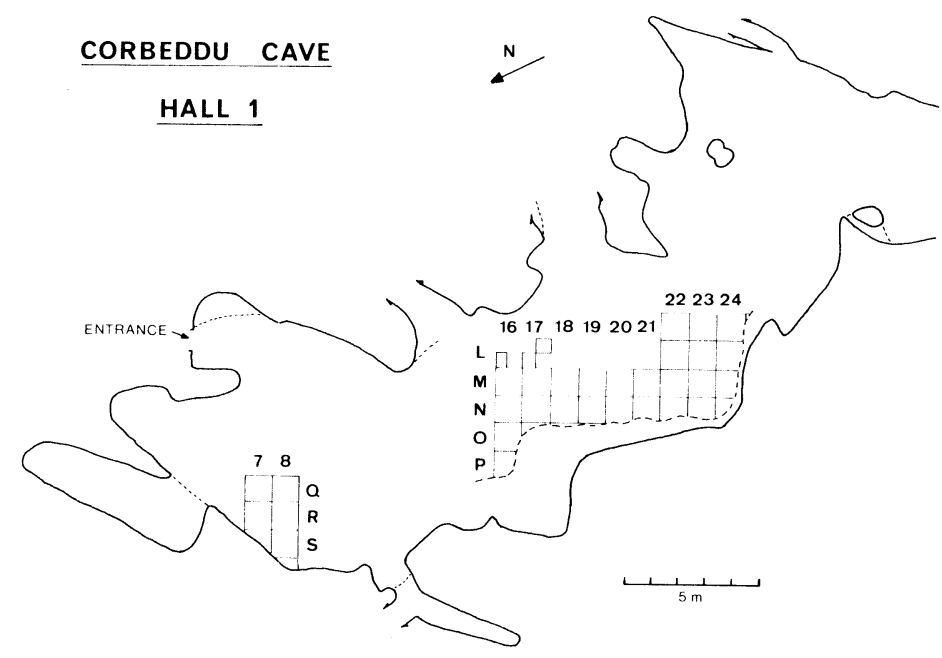

Fig 1. Plan of Hall 1 of Corbeddu Cave, Oliena, Sardinia, showing the excavated area

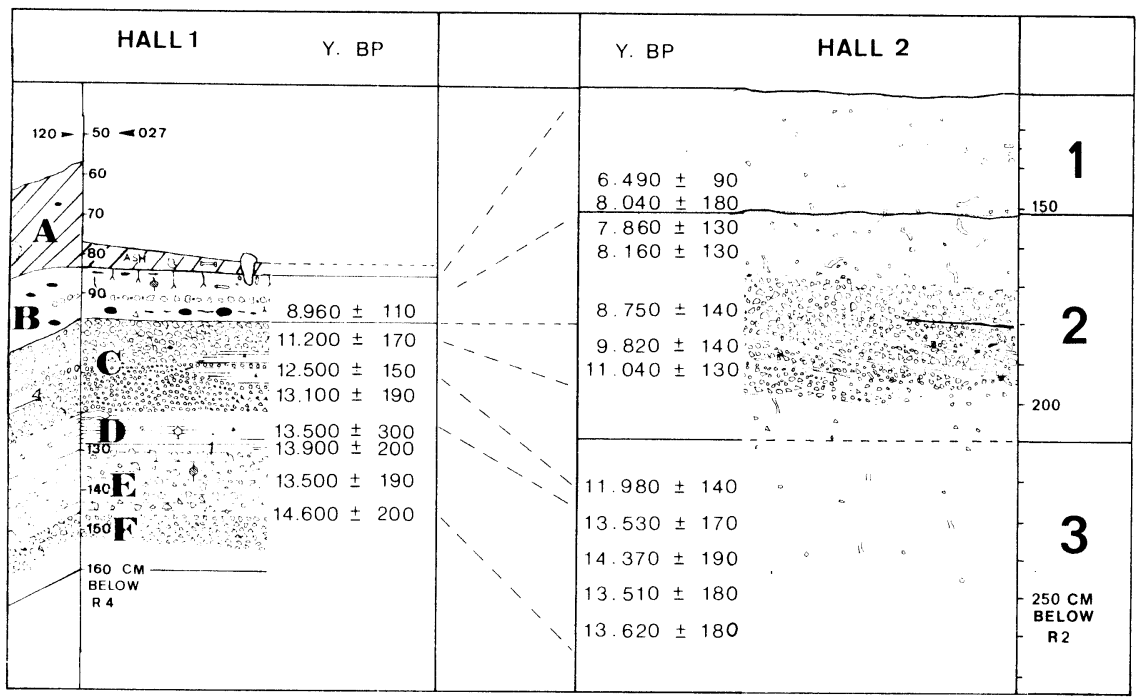

Fig 2. Correlation between the stratigraphic levels of Hall 1 and Hall 2 based on ${ }^{14} \mathrm{C}$ dates obtained from charcoal and bone measured by AMS at the R J Van de Graaff Laboratorium, Utrecht. 
Sample UtC-718 is a fragment of a deer bone collected in quadrant L22 at a depth between 180 and $220 \mathrm{~cm}$ below datum R4, dated to verify a previous analysis (UtC-243, 25,7000 $\pm 400 \mathrm{BP}$, Klein Hofmeijer et al, 1987b). The age was considered representative of the top of layer $F$, based on lithological correlations between quadrants R07 and M17. The age, 17,700 $\pm 200 \mathrm{BP}$, of UtC-718 indicates that either this correlation is not correct or that the age of the small bone of $P$ sardus (UtC-243) should not be considered the age of the layer in which it was found. At our present level of knowledge we can only conclude that the second fossiliferous unit of Hall 1, which has a minimal depth of $160 \mathrm{~cm}$ below R4 in quadrant N16-18, is older than $14,600 \mathrm{BP}$.

\section{THE LITHIC INDUSTRY}

Three lithic industries evidence human presence on Sardinia at three different time intervals during the Pleistocene. The oldest phase representing the Lower Paleolithic is documented by the Riu Altana industry of Riu Altana (Arca et al, 1982a; Martini \& Pitzalis, 1981, 1982), which has been attributed to evolved Clactonian with Protolevallois elements and dated to an early period of the Middle Pleistocene.

A second, more recent facies appears in the region of Anglona in northern Sardinia, characterized by a flake industry that lacks bifaces, generally known as Clacto-tayacien. This facies is the best represented in Sardinia by the Sa Pedrosa-Pantallinu industry exposed in situ on a glacio-fluvial Riss terrace. The industry correlates with other contemporaneous Tayacien and Evenosian assemblages from southern France (Arca et al, 1982b; Martini \& Pitzalis, 1981, 1982).

The only site in Sardinia that documents human occupation between the Riss glaciation and the Neolithic is Corbeddu Cave (Sondaar et al, 1984, 1986) The lithic assemblage from the pre-Neolithic layers of Corbeddu Cave is not abundant; however, it succesfully demonstrates the method of manufacture. The most important part of the material comes from the main excavation pit in Hall 1 (Fig 3,1-9), while only a few elements come from Hall 2 (Fig 3, 10-11). The raw material used most prevalently is a local form of silicified limestone, some flint and rarely quartz or goethite.

The oldest industry was found in layer E-F in the first hall (ca 14,000 $\mathrm{BP})$. The lithic assemblages of overlying layers $\mathrm{D}$ and $\mathrm{C}$ are not abundant but are similar to the oldest. Together they represent ca $2000 \mathrm{yr}$ (Fig 2). The short time intervals between these layers and the homogeneity of the industrial assemblage justifies a general description of the material (Klein Hofmeijer et al, 1987a). Chronologically, the lithic assemblage of Corbeddu cave is situated in Würm IV and is equivalent to the Evolved and Late Epigravettian of the peninsula.

Unflaked limestone bifaces occur frequently (Fig 3: 1-2, 6-9). They are all fairly symmetrical and regular in shape, usually triangular, and never polyhedric; one of the two faces is always smooth. They are small and short. Two types of flaked artifacts are also found: those removed from the core and those with a variety of back ribbing, indicating that the core was frequently used (Fig 3: 3-5). The use of unflaked artifacts was probably intentional and not determined by the nature of the common raw material, lime- 


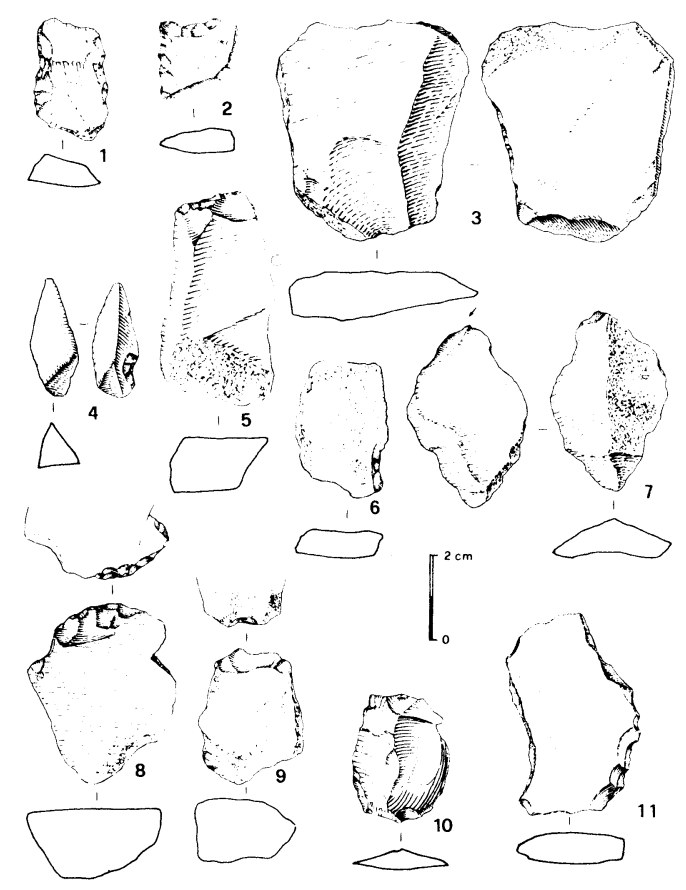

Fig 3. Lithic tools from Corbeddu Cave (Fig by G Fabbri); Hall 1: 1, limestone layer E; 2, limestone layer C; 3, limestone layer C; 4, flint layer $C$; 5 , limestone layer E; 6 , limestone layer D; 7, limestonc layer D/E; 8 , limestone layer D/E; 9, limestone layer E. Hall 2: 10; flint layer 2; 14,-limestone layer 3

stone,for we also found limestone artifacts that exhibit good flaking techniques. Flint artifacts (Fig 3: 4, 10) are also present.

The assemblage includes mostly scrapers, denticulated and scaled pieces. Although there are not enough artifacts for a quantitative study, the industry seems to be generic and undifferentiated. Retouch is rarely done with care and continuity on one or two sides of the piece (Fig 3: 1-2). More often it is summarily executed and incomplete. That this second type of retouch is intentional is confirmed not only by its morphology, but also by the direction of the retouch itself which is in one direction or the opposite, but never alternating. On the scaled pieces (Fig 3: 8-9), all on unflaked bifaces, the retouch is always located on one of the two shorter sides and its purpose seems to be to obtain a short cutting edge. This retouch is never accompanied by other kinds of retouch or unintentional flaking. This summary retouch technique is not exclusively related to the limestone as the most carefully retouched pieces were made of limestone.

Summarizing, we can say that the lithic manufacture of Hall 1 of Corbeddu Cave is undifferentiated in appearance and style, without the typological attributes that characterize contemporary industries of continental Italy, and with a scarcely organized technology and choice of artifacts.

The later occupation of the cave represented in Layer 2 of Hall 2, is dated to the end of the Pleistocene or the beginning of the Holocene (Fig 2). However, this assemblage is too poorly represented here for full evaluation. 


\section{CONCLUSIONS}

We conclude from the anthropological and paleontological data that humans were present in Corbeddu Cave from at least 14,600 BP. The human fossils show some unusual characteristics that may be related to endemism. The lithic and bone industries are not comparable to contemporary assemblages from the mainland. These features indicate the existence of an endemic pre-Neolithic settlement which must have been developed during a relatively long period of isolation on the island. The economy must have been based on hunting island fauna, indicating a remarkable equilibrium between the people and their limited variety of prey.

\section{REFERENCES}

Arca, M, Martini, F, Pitzalis, G, Tuveri, C and Ulzega, A, 1982a, Il Paleolitico dell' Anglona (Sardegna settentrionale). Ricerche 1979-80: Quad Sopr Archeol prov Sassari e Nuoro, Sassari.

1982b, Il deposito qauternario con industria del Paleolitico inferiore di Sa PedrosaPantallinu (Sassari): Riv Sci Preist, v 37, no. 1-2, p 31-53.

Klein Hofmeijer, G, Martini, F, Sanges, M, Sondaar, PY and Ulzega, A, 1987a, La fine del Pleistocene nella Grotta Corbeddu in Sardegna: fossili umani, aspetti paleontologici e cultura materiale: Riv Sci Preist, v 41, no. 1-2, p 1-36.

Klein Hofmeijer, G, Sondaar, PY, Alderliesten, C, van der Borg, K and de Jong, A F M, 1987b, Indications of Pleistocene man on Sardinia: Nuclear Instruments \& Methods, v B29, p 166168.

Martini, F and Pitzalis, G, 1981, Il Paleolitico in Sardegna, in La Sardegna dalla origini all'etă classica: Milano, Ed Scheiwiller.

1982, Il Paleolitico inferiore in Sardegna: Atti XXIII Riun Sci Ist Ital Preist Protost, Firenze, p 249-258.

Sanges, M, 1987, Gli strati del Neolithico antico e medio nella Grotta Corbeddu di Oliena (Nuoro). Nota preliminare: Atti XXVI Riun Sci Ist Ital Preist Protost, Firenze, p 825-830.

Sondaar, PY, de Boer, PL, Sanges, M, Kotsakis, T and Esu, D, 1984, First report on a Paleolithic culture in Sardinia, in The Deya conference of prehistory: BAR Internatl ser 229, p 29-47.

Sondaar, PY, Sanges, M, Kotsakis, T and de Boer, PL, 1986, The Pleistocene deer hunter of Sardinia: Geobios, v 19, p 17-25.

Spoor, C F and Sondaar, P Y, 1986, Human fossils from the endemic island fauna of Sardinia: Jour Human Evolution, v 15, p 399-408.

van der Borg, K, Alderliesten, C, Houston, C M, de Jong, A F M and van Zwol, N A, 1987, Accelerator mass spectrometry with ${ }^{14} \mathrm{C}$ and ${ }^{10} \mathrm{Be}$ in Utrecht: Nuclear Instruments \& Methods, v B29, p 143-145. 